\title{
Perception of Creativity in International Franchising Business Concepts - Comparison Analysis Between Franchisees and Franchisors
}

Vendula Machackova

\section{Abstract}

This paper deals with the topic of creativity and perceived freedom of creativity in international franchising business concepts. It analyses various areas of daily business operations and the franchising business concept as a whole. Its focus is aimed at comparing the perception of level of freedom given in these areas to franchisees by the franchisors and its objective is to find out where these perceptions differ between franchisees one side and franchisors on the other. The model of franchising is not described and the article assumes that the reader is familiar with this business model. The purpose of this article is to analyse and present the situation of creativity in the sector of international franchise businesses. As international franchising is in the focus of this article, topics such as cross-cultural environment in franchising models and creativity across cultures are covered. The method used to collect the data for further analysis is running an empirical research among two populations - franchisees and franchisors from several franchising business concepts active in international environment. Representatives from the two populations were asked to evaluate the level of freedom of creativity given or applied in their franchising business concepts. Respondents were answering an online survey, assessing ten different areas in daily business on a scale from one to five, ranging from no creativity allowed and strict governance by rules defined in the franchise concept to high level of creativity and freedom. Findings from both side of the franchise business partnerships, franchisees and franchisors, are presented including the test of homogeneity of proportions. Therefore some implications exist for further discussions and research, if franchising at all is, in its essence, a method of business concept, which enhances and facilitates creativity, or if creativity is perceived as a danger to franchise system that would harm its global unified approach which is the key principle of the franchis unified brand and concept strategy.

Keywords: International franchising, creativity, cross-cultural environment, test of homogeneity of proportions 


\section{Introduction}

This paper describes and analyses the issue of creativity freedom level in international franchising. The nature of the problem is based on the fact that franchise as a business concept runs its business operations in accordance with strictly defined rules and unified policies, with implementing numerous guidelines and provision stated in franchises operational manuals that govern all areas of business their operations to the very last details.

The reason for investigation of the area of creativity freedom among various franchise concepts is the fact, that from some previous research done in franchising field, it has come up that perception and understanding of the level of freedom and creativity differs between franchisees - from the viewpoint how much freedom and creativity they are given - and franchisors - from the viewpoint of how much freedom and creativity their concept give and allows to their franchisees.

The purpose of the study and this paper is to analyse to which extent creativity is given by franchise systems, when looked at from the perspective by both the franchisors and the franchisees, it compares how do the both populations evaluate the creativity level in various areas of their company operations ranging from corporate identity and global branding, through product marketing, sales and business development, administration, to IT and technologies, finance and accounting and human resources management. One more aim of the article is to open a question for further potential if at all creativity and franchising match together, or when speaking about creativity, there is no space for it in franchising business concepts.

For this article 846 franchise systems were contacted with questions related to creativity. The method of investigation used was an online survey with three questions. The recruitment of respondents has been conducted in the way of direct e-mails sent to previously random selected representatives from various franchise sectors. It was managed to collect 127 sets of responses from representatives from both populations franchisors and franchisees. Upon collecting the data from the online survey with three closed questions, a follow-up research was done in internet sources and among selected franchises to evaluate the findings and discuss individual topics in more details.

The scientific aim of this paper is to investigate whether and how franchising and individual franchise systems facilitate and enhance creativity, if at all. Franchising covers wide rage of business fields in global economy and therefore from macroeconomic perspective has significant impact on economy output, production and employment. From microeconomic perspective it mainly has a direct effect on the competition model and structure of market in numerous areas both on local, national and international levels (real estates, restaurant and hotel business, schooling, car rental, etc.), level and richness of supply of goods for customers. If creativity and innovation are seen as a major source of economic growth and continuous development in economics today, franchising should not hinder creativity; otherwise it can be left behind independent enterprises with independent structures and entrepreneurial innovation enhancing environments.

The research predicts that creativity can be found only in selected and limited areas and samples of franchising systems, whereas some areas are far from allowing creativity. Creative industries as a sample representative sector with a high level of creativity influencing the business success are not very often seen run as franchise system.. 
Implications for creativity presence in franchising business models are discussed for various areas in the franchising business model such as global branding, marketing and advertising, human resources, finance and accounting, administration etc. Comparing the two populations with representative samples from both franchisees and franchisors, test of hypotheses - using the chi-square test of homogeneity, was conducted. The goal is to find out, study and clarify if the level of freedom of creativity given and received in franchising model based systems is perceived identically by the franchisees and the franchisors. The null hypothesis states that the proportion of franchisees who assess the freedom of creativity in the system at a certain level is identical to the proportion of franchisors perceiving it the same. As there are ten different areas where the perception of level of freedom of creativity was assessed, the same hypothesis testing is conducted for all these ten areas by using the same procedure and statistics method.

Also based on previous research and knowledge of the franchising environment, there are certain predictions which will be studied in more details and analysed, that in some areas the level of freedom for creativity in general is higher than in some others. It will be described and compared, how it differs between these areas and if perception again is the same or different when looked at from the perspective of the two populations in the research target.

\section{Theoretical background}

\subsection{Creativity across cultures}

Culture as a term has many different meanings and definitions, as it can be found in various literature sources, but for the purpose of this paper, culture will be understood in its definition as an integrated pattern of human knowledge, beliefs, and behaviours that arise from social leasing, the set of shared attitudes, values, goals, and practices that characterizes a certain region or nation. This paper works also with the definition of culture by Sternberg (Sternberg, 2011, p. 273), who sees culture as

"a shared system of cognitions, behaviours, customs, values, rules and symbols concerning the manner in which a set of people interact with their social and physical environment."

Definitions of culture in a cross-cultural environment have been defined for example by Hofstede, who defines culture as "the collective programming of the mind that distinguishes the members of one category of people from another" (Hofstede, 1990, p. 4). When we look at characteristics of culture from various angles we learn that: (1) culture is learned and socially transmitted from generation to generation, (2) culture is identified at the society level and following geographic boundaries, (3) culture can be further categorised to subcultures within it, (4) culture is dynamic and changes over time.

The link to creativity here can be followed: social transmitting from generation to generation definitely applies to culture, however as creativity is strongly embedded in and individual the generation heritage here can be loosened. Society level definitely influences the life-style and social constructs, where social structures for sure can either restrict or enhance creativity, dependent on various factors described further below. Geographic boundaries and presence in diverse regions and nations also influences the level of creativity through its customs, values, rules and symbols typical for that particular region. Various subcultures implicate existence of various approaches and perception of creativity even within one region. If culture is dynamic and changes over 
time, it can be assumed that creativity and innovation within the culture is one of the engines that actually move the culture to evolve. This already is above the scope of this paper and would lead to various discussions and hints for further research.

\subsection{Creativity in international business environment}

The concept of creativity has been widely researched in numerous areas of psychology, organizational behaviour, marketing and management. In international environment (which we will look at as the space for international franchising) or let's say from a global viewpoint, there are two main streams that creativity can be looked at and defined. Definitions of creativity in Western cultures (USA, Canada, and Europe) name features such as: "novel" and "appropriate" and creativity is associated with either an intellectual giftedness or with a relationship to an observable product (Hughes and Drew, 1984). So in general, in Western cultures, creativity is related to a product, outcome. Also Sternberg and Lubart (1999) define creativity as "the ability to produce work that is both novel (i.e. original, unexpected) and appropriate (i.e. useful, adaptive concerning task constraints).

In Eastern cultures, on the other hand, we find definitions of creativity such as those by Chu, Kuo or Mathur: "creativity is a state of personal fulfilment, a connection to a primordial realm, or the expression of an inner essence or ultimate reality”, as Sternberg summarises in his Handbook of Creativity (1999a). Another example, Hinduism sees creativity as spiritual or religious expression rather than an innovative solution to a problem. Hallman states: "To create is to imitate the spiritual” (Hallman, 1970).

Culture may influence the overall level of creative activity. Creativity may be stimulated or hindered by cultural features such as worldview and the value placed on conformity or tradition (Sternberg, 1999b). Under worldview we understand the culture's conception of the nature of the world and people's role in the world. Collectivist vs. individualist cultures, beliefs and values, conformity and tradition as described by Hofstede (Hofstede, 1996), will also strongly influence the level of creativity seen in various areas and aspects of life both in private life and society, thereof both in individual and company business activities.

If we look at culture as a channel for creativity, we can study closer various forms of creativity, such as social structure in relations to creativity, language and its relation to creativity. Cultures can restrict creativity based on social structure, its hierarchy, traditions, and professional dominance. Creative thinking is more supported by society where democratic system, market economy and democracy are pursued compared to those economies or society systems, where other stricter and tighter regimes govern life through numerous organisations and institutions with large control. The task is to find which social structures are those that enable creativity in franchising systems that appears in developed and developing market economies and therefore by social structures creativity should not be restricted there.

The social environment can influence both the level and frequency of creative behaviour (Amabile et al., 1996). Franchising systems do also form to a certain extent its own social environment. Therefore the social environment of franchise system will be a strong influencer of creativity allowed therein.

As in international franchising we are talking about coverage of various nations and countries where numerous diverse languages are spoken. With respect to country of 
origin and language of the franchisor an important aspect is also a subject studying the influence and link of language and creativity. As among many for example Whorf said: "language shapes thought" (Whorf, 1956). In his findings he suggests that language as in integral part of culture may restrict the ways that people can creatively conceive a problem. Language structures categories and expresses a culture's understanding of the world (Lakoff \& Johnson, 1980). There also has been a positive link between bilingualism and creativity observed by few researches (Jacobs and Pierce, 1966, Ricciardelli, 1992, Simonton, 2008). Therefore in this perspective also language may be one of important influencers of creativity enhancing or restricting culture within a franchise network, as most of the franchises run across borders of their country of origin do deal with two languages used in business communication.

\section{Creativity in international franchising}

Based on creativity perception Western vs. Eastern streams described above, when applied in international franchising, both goods production or service offerings aimed, it may-be perceived and understood from these different viewpoints, when we research franchising systems in Eastern and Western cultures. Most of the franchise businesses presented in the further research are in Europe and their franchise concept originally come from and reside in Western Europe or US, so mainly the stream based on Western definitions can be observed.

Franchising as a business model and managerial system is in its essence full of rules and regulations that are set by the franchisor to keep the consistency of business models, products and services the same all over the globe. Franchisee entrepreneurship and business operations are strongly limited and governed by provisions set in the franchising contracts, operating handbook, various guidelines, best practices and standards of operations. For this simple reason and basis of the franchising system there may not seem to be much room left for creativity.

Creativity however is initiated at the individual level. Variables such as personality, motivation and expertise are related to creativity at individual level. Therefore if creativity should be enhanced, it has to go down to the level of an individual franchisee or employee and vice versa, if the level of creativity allowed dopes not correspond with the creativity level perceived as optimal by an individual it can lead to discouragement and de-motivation in his or her individual activities and performance.

Should innovation and continuous development and move correspond with evolution of customers' needs and expectations, flexibility allowing franchisees to be creative and to be able to experiment is necessary to a certain extent. There exists an assumption, which was not however verified in this research, that rules are less within a smaller franchise than they are within more established and bigger organisations. In this paper the size or lengths of franchise existence will not be a decisive criterion, level of creativity in various franchise systems will be studied regardless the size of the franchise.

As in any other businesses, organisations, institutions or society patterns, it is communication within the franchising network not only between a franchisor and a franchisee, but also among franchisees as peers themselves, that can enhance and facilitate the environment supporting creativity.Ideas for innovations and new approach to business tasks solutions can come up not only from franchisor and aimed at franchisees to implement them, many creative ideas can come from franchisees to franchisees or even from franchisee to the franchisor, if there is an idea that the whole 
system of franchising network can benefit from and capitalise on. A given concern common to all franchisees, questions, tasks to solve can lead to new thinking. It does not have to be strictly governed by a franchisor, who may not have anticipated such an issue to be solved in the business daily operations when creating rules and guidelines applicable for franchisee contained in the franchise contract or operating handbooks.

It is the franchisees and their points of sales or franchise affiliates that are the closest to the end customer, live out there in the market environment where their business operations meet on daily business their clients with their needs and requests, face direct competition, face regulations, limitations from states and communities, meet various challenges in the form of new living philosophies, newly established value systems and arising habits. To create new solutions to these tasks, all these aspects should be the reason to allow the franchisees to bring in their own creativity. However, any changes, that franchisees plan to do in their business, whether small or big, the franchisor has to be informed about these in advance, not to get into infringement of franchising contracts, operating book and other rules set in the system, but also to understand and test if the new creative approach, product, service, solution does correspond with the general franchise strategy and philosophy. Franchisees pursuing innovative efforts and bringing novel things into their business and into the whole franchising system and network should not be regarded as an envy or danger. The intellectual creativity in a human being mindset can involve divergent thinking and various problem-solving skills. Flexible and original approach when solving tasks are of course competences that every entrepreneur can benefit from, so even a franchise system should not regard these as negative.

When we look at the link between franchising systems outputs and creativity, franchise business organisations bring creativity to life through their products or services and also creativity influences their internal system, processes and innovations of the whole business model as such. To be able to provide to the economy and society products and services that customers desire and therefore serve to meet their needs, the key source for success is that companies have to deliver innovative products. Social and physical environment are set by thy system and franchise organisation culture and structure. As said before, this influence strongly the level of creativity that is in general either higher or lower across the whole system. Organisational culture and climate in an international franchising system depend not on the size, more on the area in which franchises system belongs to and on the country of origin of a franchisor and therefore cultural background. The ability to generate and market creative ideas when introducing new products and services and related marketing initiatives into the markets as a response to changing customers' needs is one of the key success factors of a firm in every changing environment with supply surplus. These features (changing environment, supply surplus) can bee found in majority of markets where franchise systems operate and run their businesses.

\section{Creativity dimensions for franchising}

Consistently with Amabile (1983a), the two distinct dimensions of creativity are used: first, the dimension of unique differences (i.e. novelty dimension) and second meaningfulness to target (i.e. features perceived as appropriate and useful to target) when studying creativity impact on franchise output. As the area of franchising systems and franchise business model is considered, the novelty dimension has been looked at from the viewpoint of a franchisee, being able and allowed, by the franchisor and the 
whole franchise, to execute services or products or for example to customize its work environment differently from the franchise system rules. The meaningfulness to target is seen from the viewpoint of a franchisee, where the novel approach or feature or product has significant impact on their business output and performance or is perceived as appropriate and benefiting with regards to target customers, which would than mean a competitive advantage for the company compared to its competitors.

As Amabile argues, "both dimensions must be included in the concept of creativity, because the target audience may perceive ideas as weird or bizarre if they are novel or unique but carry no meaning for the audience" (Amabile, 1983b). Franchise businesses do mostly run on a very pragmatic and rational basis, where all process and decisions are strongly supported by a certain economic optimisation and therefore all things that should be regarded as worth to apply and execute have to be meaningful for all stakeholders involved, i. e. for a franchisor, franchisee, its employees and customers.

Local market adaptation of products and therefore certain level of creativity allowed in development and placement of new products or services to the market is a premise for good performance of business and organisations in the international business environment. If we have seen that cultures and therefore customer vary around the globe, it would probably be wrong to anticipate that completely unified product or service would be able to satisfy needs of customers elsewhere. Franchising areas such as hotel chains, restaurants and fast-foods, retails of all kinds of goods, automotive services, education, and others, can be based on a unified core product to a certain extent, but for sure this can not work $100 \%$ the same in all places around the world.

It has been supported that creativity and innovation are keys to the growth and success of a firm (Andrews and Smith 1996, Sethi, Smith and Park, 2001). If we perceive and use creativity as a construct preceding innovation when bringing a new product onto the various markets as a response to its needs, we for sure would find creativity also in international franchising. Franchises also have to enhance innovation and creativity, as without innovation of their offer, they would not succeed in such high competitive markets, where most of the franchises are active. "All innovation begins with creative ideas,” as is said by Amabile et al. (1996). As S. Im and J.P. Workman write in their article on "Market Orientation, Creativity, and New Product performances in High-Technology Firms” (Journal of Marketing, April 2004, p. 114), "creativity by individual and teams is a starting point for innovation”. This is valid not only for high-technology firms though.

\section{Creative industries and franchising}

As an understanding of statement and definition in numerous sources 'creative industries' is a relatively new definition of the industrial components of the economy in which creativity is an input and content or intellectual property is the output. The size and growth of this sector in $21^{\text {st }}$ century is significant for the global economy and the rapid growth of these industries have created an important sector. Economically these sectors are significant in terms of their contribution to income, employment and trade. In the times of knowledge economy and information economy, it is exactly the creative industries that cover whole range of economic activities. The whole sector can be also referred to as the creative economy (Howkins, 2001a). In his book 'The Creative Economy' Howkins encounters following industries and fields of economy into this sector: advertising, architecture, arts and crafts, design, fashion, film, music, performing 
arts, publishing, $\mathrm{R} \& \mathrm{D}$, software, toys and games, TV and radio, and videogames (Howkins, 2001b).

As Landry and Bianchini say: "the industries of the twenty-first century will depend increasingly on the generation of knowledge through creativity and innovation," (Landry \& Bianchini, 1995).

When sorting the rated 500 top franchises in Europe by industry, we find that there are various groups and subgroups.Most of franchises can be found in the sectors of automotive (35), food (100), various types of retail (145), real estates (23) and health and beauty (59).

\begin{tabular}{|c|c|}
\hline Franchising area/field & Amount \\
\hline $\begin{array}{l}\text { Automotive: automobile renting and leasing, car wash, car cleaning, exhaust tyre } \\
\text { and windscreen repair, products and services }\end{array}$ & 35 \\
\hline Building, construction & 10 \\
\hline Business: financial services, products and services & 25 \\
\hline Commercial hygiene & 8 \\
\hline Computer, electronic and Internet services & 11 \\
\hline Couriers & 5 \\
\hline Dry cleaning, laundry & 6 \\
\hline Education: children & 18 \\
\hline Food: baked goods, donuts and pastry & 13 \\
\hline Food: candy, popcorn and snacks, ice-cream and yoghurt & 10 \\
\hline Food: convenience stores, products, distribution, specialty shops, others & 40 \\
\hline Food: restaurants & 26 \\
\hline Food: sandwich bar and coffee-shop & 11 \\
\hline Health and beauty: hairstyling & 20 \\
\hline Health and beauty: opticians, tanning, other & 34 \\
\hline Health and beauty: sports and recreation & 5 \\
\hline Home services, housekeeping, cleaning, maid services & 12 \\
\hline Hotels & 12 \\
\hline Miscellaneous & 7 \\
\hline Photo, Frame, Art & 9 \\
\hline Real Estate & 23 \\
\hline Retail: appliances, bookshops & 3 \\
\hline Retail: clothes and footwear & 54 \\
\hline Retail: florist, gardening products, DIY, pets & 18 \\
\hline Retail: household furnishing & 29 \\
\hline Retail: Jewellers & 6 \\
\hline
\end{tabular}




\section{Franchising area/field}

Retail: other

Travel

Source: http://www.franchiseeurope.com/top500/

Study made from the opposite direction, when searching for franchises in areas that are defined as a part of creative industries we come to following findings (see table 2 below): the highest number of existing franchises can be found in the fashion field (15) (the clothing and shoes pure retail franchises have been taken away), the second largest group is advertising, with 9 franchises in subgroups such as print, signs, graphics, direct mail and internet advertising, the third group already comprises of 7 franchises only -art. Under arts, such franchises like photography and framing are counted. There are 5 franchises in design and video games. Three and two franchises can be found in the sector of toys and games and music respectively. Publishing and TV and radio (DVD rental) contains 1 franchise each. There are also areas such as film, performing arts, R\&D and software, where there no franchise can be seen.

\begin{tabular}{|l|c|l|}
\hline Advertising & 9 & $\begin{array}{l}\text { Advertising franchise: } \\
\text { Print, signs and graphics (5) } \\
\text { Direct mail franchise (1) } \\
\text { Internet (2) }\end{array}$ \\
\hline Architecture & 2 & \\
\hline Art & 7 & $\begin{array}{l}\text { Photography (1) } \\
\text { Framing (5, 4 in US, 1 in Canada) } \\
\text { Web design (1) } \\
\text { Graphic design (1) } \\
\text { Video production (0) }\end{array}$ \\
\hline Crafts & 1 & More a shop for crafts-men \\
\hline Design & 5 & These are more home decor franchises then real design \\
\hline Fashion & 15 & Real fashion, not pure clothing and shoes retail \\
\hline Film & 0 & $\begin{array}{l}\text { Film franchise is a different type of business, not real “franchises" in } \\
\text { its definition essence }\end{array}$ \\
\hline Music & 2 & Instrument repairs, teaching music, music sales \\
\hline Performing arts & 0 & \\
\hline Publishing & 1 & \\
\hline R\&D & 0 & \\
\hline Software & 0 & \\
\hline Toys, games & 3 & \\
\hline TV and radio & 1 & DVD rental \\
\hline Video games & 5 & \\
\hline
\end{tabular}

Source: http://www.franchiseopportunities.com/industries/2475/Advertising_Franchis.htm 
These findings implicate that the more creativity is required in the sector, or the more creativity based is its outcome, the less the business or area is appropriate for running a franchise model. But this prediction has not been the primary aim of this research and therefore will not be studied any further in the paper.

\section{Empirical research methodology}

For this paper research online survey with three closed questions, internet sources search and follow-up structured dialogs have been conducted. 846 franchise systems were contacted with questions related to creativity. It was managed to collect back 127 sets of responses from representatives from both populations - franchisors and franchisees. Upon collecting the data from the survey, a follow-up research was done in internet sources and among selected franchises to evaluate the findings and discuss individual topics in more details. Creativity was studied among the franchising system with finding short answers to questions related to level of creativity in the respective franchise systems and these answers were further studied in more details in exploratory field interviews in 12 different franchise systems.

Looking from the other direction again, providing empirical insight into the debate of whether franchising area and business model as such facilitate or impede creativity, all assumptions of limitations given to creativity in a franchising model were approved.

\subsection{Research questions}

The main research question is whether or not the perception of creativity differs between the two populations - franchisees and franchisors, when it gets to the level of freedom for creativity allowed. The test of homogeneity in multinomial samples will be used to test the hypotheses that proportions are not identical but differ in the way of franchisees feeling more restrictions and authoritative rules limiting the level of their creativity freedom given by the franchisors in various franchise systems.

The second part of the research question and research aim is dedicated to the mentioned areas of franchise business daily operations, and studies to which extent these areas allow some space and freedom for creativity of the franchisee.

\subsection{Scope of investigation}

Several elements of the franchising systems were studied, where creativity is less or more allowed from the essence of the franchise model and franchises systems. These elements cover: local corporate identity and branding, product amendments and variability, marketing and advertising, sales and new business development, project management, client care, IT and technology, administration, finance and book-keeping and human resources management areas. Responses were collected from 69 respondents representing franchisors and 58 respondents representing franchisees. Respondents to questionnaire are from the following franchise areas: Accounting and Tax Services, Automotive Products and Services, Auto Rentals, Children's Services, Education, Food and Restaurants, Maintenance and Cleaning, Real Estates, Retail stores: specialty and others, Travel and Tourism.

Franchising organizational culture influences creativity in all areas that have been studied. From different answers collected among franchisor and among franchisees, it also can be figured out that also such features like professional dominance and the roles 
and power of leadership in a social structure play a significant role. Even though the franchisor would not feel the power or restriction of creativity in some areas as that strong, the franchisees perceive it differently. This implicates, that written rules and guidelines of a franchise system are considered as extremely strong and binding by the franchisees, even though the franchisor sees that the room for creativity is sufficient. The organisation goals as such are set a franchise level as well and therefore all areas that play the role of operational strategies to fulfil the goals and follow the global franchise strategy are subordinate to this with less or more limited levels of creativity in each of these area, to assure that the level of creativity is still in compliance with assuring to fulfil the goals set.

\subsection{Research findings}

The Table 1 and Table 2 summarise results of the survey findings collected. The first one presents results from the sample of Franchisors, the second one from Franchisees.

Table 1: Franchisees' responses to the questionnaire on levels of creativity in various areas of their franchise business $(n=58)$

\begin{tabular}{|l|c|c|c|c|c|c|}
\hline \multicolumn{1}{|c|}{ Franchisee's responses (n=58) } & 1 & 2 & 3 & 4 & 5 & $\begin{array}{c}\text { Response } \\
\text { Count }\end{array}$ \\
\hline Local Corporate Indentity and Branding & 34 & 24 & 0 & 0 & 0 & 58 \\
\hline Product Amendments and Variability & 32 & 19 & 5 & 2 & 0 & 58 \\
\hline Marketing and Advertising & 26 & 17 & 9 & 6 & 0 & 58 \\
\hline Sales and New Business Development & 17 & 12 & 8 & 6 & 15 & 58 \\
\hline Project Management & 10 & 17 & 15 & 8 & 8 & 58 \\
\hline Client Care & 19 & 9 & 10 & 12 & 8 & 58 \\
\hline IT and Technology & 18 & 17 & 16 & 6 & 1 & 58 \\
\hline Administration & 12 & 13 & 18 & 10 & 5 & 58 \\
\hline Finance and Accounting & 16 & 15 & 18 & 9 & 0 & 58 \\
\hline Human Resources Managament & 9 & 11 & 10 & 16 & 12 & 58 \\
\hline
\end{tabular}

Table 2: Franchisors' responses to the questionnaire on levels of creativity in various areas of their franchise business $(n=69)$

\begin{tabular}{|l|c|c|c|c|c|c|}
\hline \multicolumn{1}{|c|}{ Franchisors' responses (n=69) } & 1 & 2 & 3 & 4 & 5 & $\begin{array}{c}\text { Response } \\
\text { Count }\end{array}$ \\
\hline Local Corporate Indentity and Branding & 29 & 12 & 3 & 25 & 0 & 69 \\
\hline Product Amendments and Variability & 21 & 19 & 9 & 20 & 0 & 69 \\
\hline Marketing and Advertising & 15 & 21 & 22 & 9 & 2 & 69 \\
\hline Sales and New Business Development & 18 & 0 & 20 & 22 & 9 & 69 \\
\hline Project Management & 11 & 5 & 16 & 18 & 19 & 69 \\
\hline
\end{tabular}




\begin{tabular}{|l|c|c|c|c|c|c|}
\hline \multicolumn{1}{|c|}{ Franchisors' responses $(\mathbf{n}=\mathbf{6 9})$} & $\mathbf{1}$ & $\mathbf{2}$ & $\mathbf{3}$ & $\mathbf{4}$ & $\mathbf{5}$ & $\begin{array}{c}\text { Response } \\
\text { Count }\end{array}$ \\
\hline Client Care & 12 & 0 & 16 & 18 & 23 & 69 \\
\hline IT and Technology & 18 & 8 & 17 & 16 & 10 & 69 \\
\hline Administration & 18 & 5 & 17 & 13 & 16 & 69 \\
\hline aultFinance and Accounting & 25 & 13 & 3 & 11 & 17 & 69 \\
\hline Human Resources Management & 5 & 9 & 9 & 18 & 28 & 69 \\
\hline
\end{tabular}

Table 3: Definition of five levels of perceived creativity freedom in the respective franchise system

\begin{tabular}{|l|c|}
\hline no creativity allowed, strictly governed by franchise rules & 1 \\
\hline limited creativity with a lot of control & 2 \\
\hline creativity partially allowed to certain extent and under control & 3 \\
\hline quite a large level of creativity allowed under light governance and specific limitations only & 4 \\
\hline high level of creativity allowed and a lot of freedom given & 5 \\
\hline
\end{tabular}

\subsection{Statistical testing}

Test of homogeneity of the multinomial distribution is conducted, specifically the chi-square test of homogeneity due to pattern of the multinomial research data.

The data gathered from answers from franchisees and franchisors are representing the two different populations where it was used to determine whether frequency counts are distributed identically across the two different populations or not.

In the survey the two populations - franchisees and franchisors- were asked the same questions to share their feedback and perception of level of freedom and creativity given to them in the franchise business in various areas such as corporate identity, marketing, business development, IT, project management or human resources management.

Having completed statistically sufficient number of responses the chi-square test for homogeneity was used to determine whether franchisees' and franchisors' perception of freedom in creativity differ.

\subsection{Stating the hypotheses and hypotheses testing}

The null and the alternative hypotheses have been stated.

The null hypothesis states that the proportion of franchisees who assess the level of freedom of creativity in the system as 1 (no creativity allowed, strictly governed by franchise rules) is identical to the proportion of franchisors perceiving it the same; and similarly for all the other levels of freedom of creativity in the system.

As there are ten different areas where the perception of level of freedom of creativity was assessed, the same hypothesis testing has to be conducted for all these ten areas by the same procedure. 
HO:

$$
\begin{aligned}
& \mathrm{H}_{0}: \mathrm{P}_{\text {franchisees level1 }}=\mathrm{P}_{\text {franchisors level 1 }} \\
& \mathrm{H}_{0}: \mathrm{P}_{\text {franchisees level2 } 2}=\mathrm{P}_{\text {franchisors level } 2} \\
& \mathrm{H}_{0}: \mathrm{P}_{\text {franchisees level3 }}=\mathrm{P}_{\text {franchisors level } 3} \\
& \mathrm{H}_{0}: \mathrm{P}_{\text {franchisees level4 } 4}=\mathrm{P}_{\text {franchisors level } 4} \\
& \mathrm{H}_{0}: \mathrm{P}_{\text {franchisees level5 }}=\mathrm{P}_{\text {franchisors level } 5}
\end{aligned}
$$

H1:

Alternative hypothesis: At least one of the null hypothesis statements is false.

Analysis plan:

Significance level: 0,05

Test method:

The chi-square test for homogeneity is used to determine whether observed sample frequencies differ significantly from expected frequencies specified in the null hypothesis.

Degrees of freedom:

$$
\mathrm{DF}=(\mathrm{r}-1) *(\mathrm{c}-1)
$$

$\mathrm{r}=$ the number of populations $=2$ (franchisees and franchisors)

$\mathrm{c}=$ the number of levels for categorical variable $(5$ - ranging from 1 to 5 levels of perceived freedom given in the specific area)

$$
\mathrm{DF}=(2-1) *(5-1)=4
$$

Expected frequency counts:

The expected frequency counts are computed separately for each population at each level of the categorical variable

$$
\mathrm{E}_{\mathrm{r}, \mathrm{c}}=\left(\mathrm{n}_{\mathrm{r}} * \mathrm{n}_{\mathrm{c}}\right) / \mathrm{n}
$$

The test statistic is a chi-square random variable $\left(\mathrm{X}^{2}\right)$ defined by the following equation,

$$
\begin{aligned}
& \mathrm{X}^{2}=\Sigma\left[\left(\mathrm{O}_{\mathrm{r}, \mathrm{c}}-\mathrm{E}_{\mathrm{r}, \mathrm{c}}\right)^{2} / \mathrm{E}_{\mathrm{r}, \mathrm{c}}\right] \\
& x^{2}=\sum_{i=1}^{r} \sum_{j=1}^{c} \frac{\left(n_{i j}-\frac{n_{i} \cdot n_{j}}{n}\right)^{2}}{\frac{n_{i} \cdot n_{j}}{n}}
\end{aligned}
$$

where Or,c is the observed frequency count in population $\mathrm{r}$ (franchisees) for level c (1 to 5) of the categorical variable, and $\mathrm{Er}, \mathrm{c}$ is the expected frequency count in population $\mathrm{r}$ (franchisors) for level c (1 to 5 ) of the categorical variable.

P-Value: The P-value is the probability of observing a sample statistic as extreme as the test statistic. 
Using the chi-square calculator for four degrees of freedom at the significance level 0,05 - the P-value is the probability that a chi-square statistic having 4 degrees of freedom is more extreme than counted chi-square.

The chi-square critical value having 4 degrees of freedom at the significance level $\mathrm{P}=$ 0,05 is $\mathbf{9 , 4 8 8}$ table of chi-square statistics).

Table 4: Sample of franchisors' and franchisees ' responses to the questionnaire on levels of creativity in various areas of their franchise business - area of the Local Corporate Identity and Branding as an input for a chi-square test of homogeneity

\section{Local Corporate Indentity and Branding - Comparison of Franchisees and Franchisors}

\begin{tabular}{|c|c|c|c|c|c|c|}
\hline Franchisee & 34 & 24 & 0 & 0 & 0 & 58 \\
\hline \multirow[t]{8}{*}{ Franchisor } & 29 & 12 & 3 & 25 & 0 & 69 \\
\hline & 63 & 36 & 3 & 25 & 0 & 127 \\
\hline & \multicolumn{6}{|c|}{$n \_i$ * $n j$} \\
\hline & 3654 & 2088 & 174 & 1450 & 0 & 58 \\
\hline & 4347 & 2484 & 207 & 1725 & 0 & 69 \\
\hline & 63 & 36 & 3 & 25 & 0 & 127 \\
\hline & 0,316366 & 0,275862 & 0 & 0 & 0 & \\
\hline & 0,193467 & 0,057971 & 0,043478 & 0,362319 & 0 & \\
\hline
\end{tabular}

\section{Chi-square statistics test}

\section{1,68175}

As the chi-square test procedure is appropriate only when the condition of data displayed in contingency table, the expected frequency count for each cell of the table is at least 5 is met, for the calculation of the chi-square statistics for areas where there have been some cells with zeros and counts less than 5 - the testing areas were cumulated together is some cases to neighbouring cells, to be able to count the correct statistics.

Table 5: Results of chi-square statistics calculations of all ten questioned areas in the franchise concepts.

\begin{tabular}{|l|c|}
\multicolumn{1}{|c|}{$\begin{array}{c}\text { Area of study of level of freedom in creativity } \\
\text { in the franchise system }\end{array}$} & $\begin{array}{c}\text { chi-square statistics } \\
\text { calculated }\end{array}$ \\
\hline Local Corporate Identity and Branding & 31,68175 \\
\hline Product Amendments and Variability & 17,33041 \\
\hline Marketing and Advertising & 10,55028 \\
\hline Sales and New Business Development & 27,06457 \\
\hline Project Management & 14,10603 \\
\hline
\end{tabular}




\begin{tabular}{|l|c|}
\multicolumn{1}{|c|}{$\begin{array}{c}\text { Area of study of level of freedom in creativity } \\
\text { in the franchise system }\end{array}$} & $\begin{array}{c}\text { chi-square statistics } \\
\text { calculated }\end{array}$ \\
\hline Client Care & 19,61774 \\
\hline IT and Technology & 14,33417 \\
\hline Administration & 10,06005 \\
\hline Finance and Accounting & 29,2998 \\
\hline Human Resources Management & 7,012991 \\
\hline
\end{tabular}

From the calculated chi-square statistics it is evident that for the first nine areas, starting from Local Corporate Identity and Branding ranging to Finance and Accounting, the tested statistic results are more extreme values than the critical chi-square critical value $\left(X^{2}>9,488\right.$. For one remaining area - Human Resources Management - the critical value of chi-square statistics with 4 degrees of freedom is more extreme than the counted chi-square statistics.

Resulting from these chi-square calculation it can be seen that except for the area of Human Resources Management we can reject the null hypotheses (chi-square $\geq \mathrm{X}_{0,05}^{2}$ ). We are rejecting the hypothesis that the proportion of franchisees who assess the level of freedom of creativity in the system identically to the proportion of franchisors perceiving it the same for these two populations.

In the area of Human Resources Management we can not reject the null hypotheses that the level of creativity in the system is perceived identically by the two populations, franchisees and franchisors. For the study of how the perception levels of creativity freedom are distributed among the levels, is also displayed and nicely observable when comparing the areas in two bar charts compared with each other.

Graph 1: A bar chart displaying the counts of answers - selected levels of freedom in creativity in all ten areas of franchise concepts - answers given by Franchisees $(n=58)$

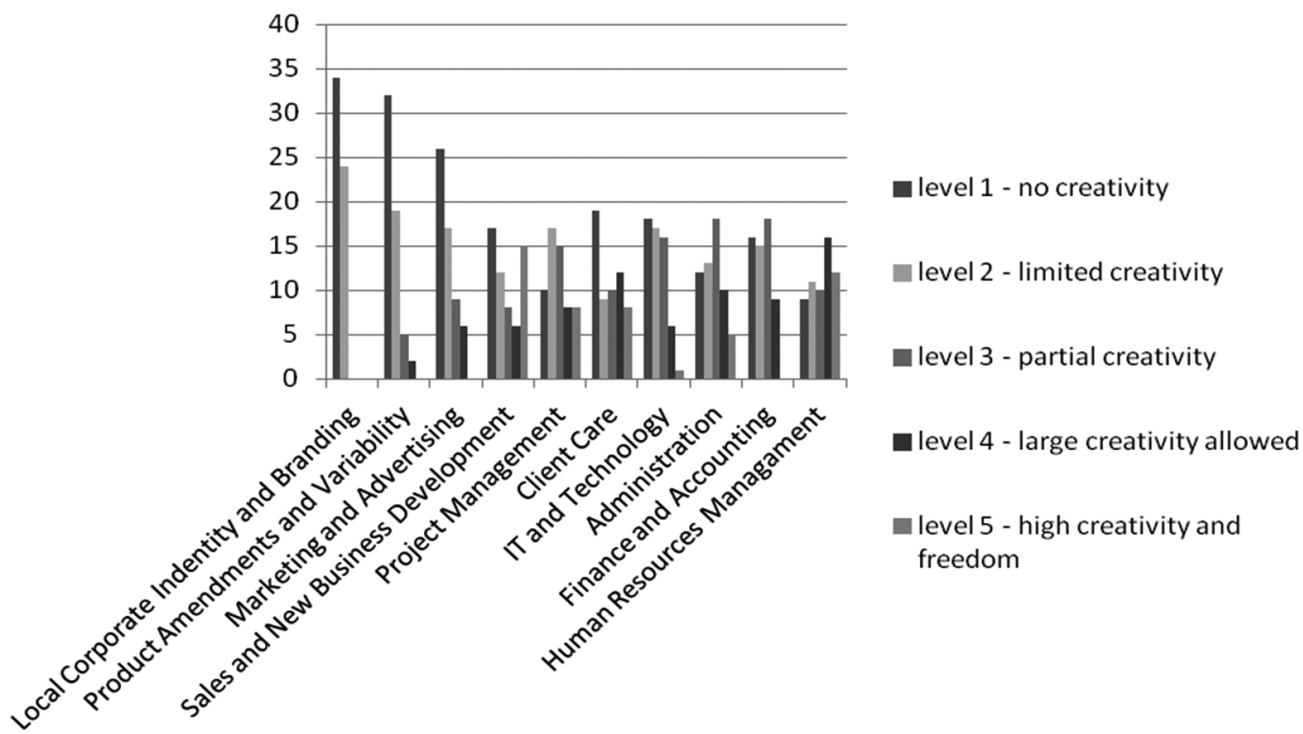


Graph 2: A bar chart displaying the counts of answers - selected levels of freedom in creativity in all ten areas of franchise concepts - answers given by Franchisors $(n=69)$

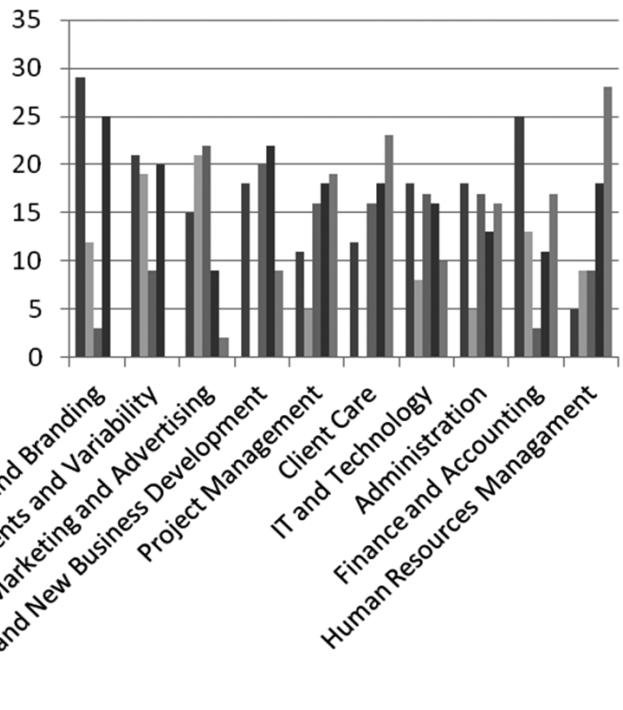

- level 1 - no creativity

level 2 - limited creativity

- level 3 - partial creativity

- level 4 - large creativity allowed

- level 5 - high creativity and freedom

At a first sight it is visible that the distributionof answers given by franchisees and franchisors is not only identical but also has different distribution pattern. The level of creativity perception when displayed graphically in two spot line charts, shows when comparing these two charts, that franchisors rend to assess the creativity as higher than franchisees in several areas.

Graph 3a and 3b: A spot line chart displaying the counts of answers - selected levels of freedom of creativity in all ten areas of franchise concepts - comparison of answers given by Franchisees $(n=58)$ and Franchisors $(n=69)$

3a-Franchisees

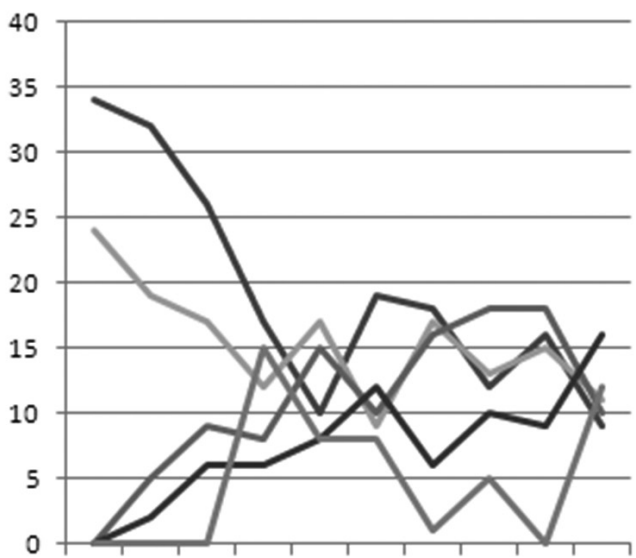

3b-Franchisors

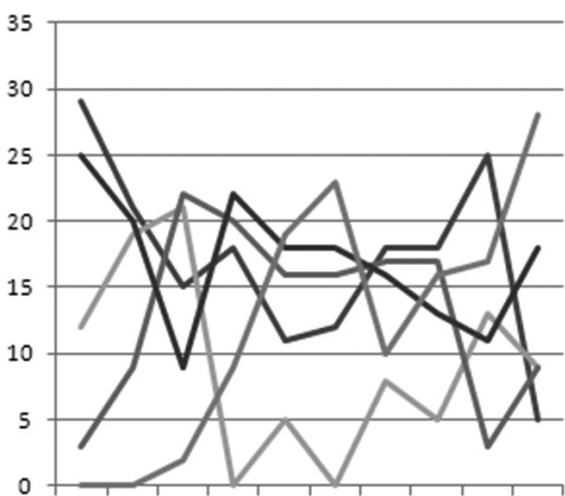




\section{Discussion}

Beside the conclusions that are resulting based on using the chi-square statistics and test of homogeneity, there have been some interesting findings achieved. Findings across all areas studied have show an interesting fact of a different perception of level of creativity given in the franchise systems when viewed from the perspective of a franchisor of a franchisee. Basically the conclusion that can be derived from the results of the research can also state the following fact: The level of creativity allowed in the franchise systems is perceived generally as higher (i.e. more freedom given, less strict rules and governance) by franchisors compared to the perception of creativity level perceived by franchisees. When studying this fact or pattern in more details, specifically in the individual areas evaluated, it also can be seen, that this pattern differs among them.

It can be further discussed in which of these the creativity allowed id the lowest and in which highest and study further the reasons why is that. Two areas, where the creativity is seen as the most and the least limited are the area of local corporate identity and branding (the most limited, the lowest room for creativity) and area of human resources (the least limited, the largest room for creativity).

In the area of local corporate identity and branding, where 29 out of 69 franchisors perceive it as "no creativity allowed" and 12 perceive this area as with "limited creativity". However, form franchisees' point of view the responses show, that "no creativity allowed" has been chosen by 34 out of 58 respondents and 24 respondents selected the option of "limited creativity with a lot of control". None of the franchisees chose higher level of creativity allowed than level 2 .

When looking at the area of Human Resources Management, situation is similar to the previous one, franchisors feel that their franchise systems offer higher level of creativity that how franchisees perceive it.

Tables and charts display the count of answers given by franchisors and by franchisees as follows: franchisors' perspective: level $1-5$, level $2-9$, level $3-9$, level 4 18, level $5-28$, whereas franchisees' perception was: level $1-9$, level $2-11$, level $3-10$, level $4-16$, level $5-12$. Again a different pattern generally observed, as franchisors perceive the freedom for creativity given to franchisees as higher than the vice versa.

\section{Detailed findings from exploratory interviews}

The findings of the second part of the research, the exploratory interviews with 12 representatives from franchisors, franchisees and franchising advisors have brought up several ideas and tools for creativity enhancement. This paper will structure them in same categories as those used in the questionnaires. They will be presented as anonymous. One of the collected answers in our research fully corresponds with the initial prediction of this paper stated in the beginning. The person commentary explicitly says: "Being a creative franchisee is often regarded as being a dangerous move, especially by the Franchisor because they view most new thinking as counter to their concept. However, many times, creative thinking has proven Franchisors wrong in restricting creative practices."

The findings of the research and evaluation done both by franchisors and franchisees and commented by respondents in the exploratory interviews shows how much creativity is allowed in various fields of franchising business model. Herein below a list of 
several areas is presented, where the research has gone further to study some samples of creativity.

\subsection{Marketing and advertising in international franchising}

If we look at the area where cross-cultural differences appear the most in international franchising, we immediately see the field of advertising. Advertising in its essence should be based on creativity and on proximity to its target audience. As advertising has to be compatible and appropriate for common cognitions, beliefs, values, patterns and symbols in the society to which it is aimed, not all advertising can be strictly defined on a global level by a franchisor. No matter that franchise brands are very often global brands or do have the ambition to become global or at least multi-national at a certain point, they still need to encounter the fact of diversity among nations and cultures and diversity in social structures, language, beliefs, values. All these influence not only customer needs but also their perception of brands, offered products and services and also communication activities and promotional initiatives aimed at them. What may work in the country of origin of a franchisor, does not necessarily have to work in other countries. Therefore even if franchise concept as such would not support too much creativity in its franchisees, it has to flexibly approach new markets and use the creativity and innovation when adapting its offer to the local customers' needs. Building creativity and innovation programmes for the teams, launching creativity enhancing initiatives, providing a range of development tools and learning opportunities for the marketing teams should all facilitate a creative enhancing environment at their workplace.

Creativity in design teams has been seen as highly supported for example in food and coffee chains (McDonalds, Starbucks) that need to attract their clients offering them something new continuously. Thomas Prowell, senior copywriter, Starbucks: „That's our ongoing challenge here, to avoid being mundane, to continue to find the excitement in the product. As long as we keep delivering that surprise our customers, we'll be successful - both commercially and creatively."

\subsection{Human resources management in international franchising}

From the hypothesis test we could see that the area of Human Resources Management is the only one, where we could not reject the hypothesis that the proportion of franchisees who assess the level of freedom of creativity in the system is identical to the proportion of franchisors perceiving it the same.

The data show that the area of Human Resources Management offers various levels of creativity but both Franchisees and Franchisors tend to see it as the area where they can be the most creative among all. For sure this can be supported by the facts learned when studying theory and literature for this paper, when the relationship between human being personality, level of motivation and creativity at work was discussed.

\subsubsection{Human Resources Recruitment}

Recruitment and new candidates hiring - each nations, culture and country has its own rules and habits, how to attract people and how to assess their real interest and match with the desired positions. Some positions are really generic and therefore do not allow much creativity in their search, attraction and evaluation. But some positions need 
a lot of unique competences and skills and therefore creativity is desired even in the stage of their recruiting process.

\subsubsection{Training and talent management}

Training and talent development can be unified at a global of franchise system level to the extent of skills and expertise that are need for the work to be performed, however soft skills and development of individual beings has to be very much based on the individual needs and therefore here flexibility and creativity has to be allowed.

Training and talent development university, it has been received well with national media, employees, clients, franchisees \& franchise prospects.

\subsubsection{Motivation of employees in the work-place and creativity}

One example of creativity that worked in operating multiple stores for a creating brand in detail stores with specialties was to create a "special fund" to benefit their employees. Motivating employees is one of the two most important things a franchisee must do to be successful. The purpose of the fund was to quickly help the hourly worker if an emergency came up for them and possibly kept them from getting to work. This would include having a flat tire, babysitter cancelling, or some other personal situation where extra money was needed immediately to help them solve a problem so they could make it into work as scheduled. Small incentive plans done for employees are appreciated and valued by them and made them feel like their employer is there to help them when it was needed. Employee motivation is a key factor in building positive attitudes among them.

The tremendous wealth creation opportunity that franchising can produce for an entrepreneur. It is a three to seven year wealth building plan for the person or partners that are willing to "plan their work and work their plan". It is not a get rich quick scheme. The upside is so much higher than trying to buy an existing business and turn it around or take it to the next level. Master franchising gives an owner a foundation to build on with the sky as the limit.

Funding, as the introduction of the ability to use retirement funds tax, penalty and debt free to start, buy or grow a business. This has proven to be one of the most creative funding resources available to the franchising and business community in decades.

\subsection{Finance and accounting}

What can be regarded as not inspirational or entrepreneurial is an opinion, but what is a really truly paradigm is that if the major focus is not on franchisee profitability a system is almost certain to fail. The franchisee that knows their numbers is far more likely to be the successful franchisee both before entry and certainly thereafter. Therefore finance and accounting definitely has to be governed not only by the franchise system, national finance and accounting laws but also by internal efficiency finance and accounting systems that help the franchisor track daily, weekly, monthly and yearly data on financial performance of their entrepreneurship, the way they need it to control and manage. 


\subsection{Financial support in franchisees loan receiving efforts}

Support in financing issues that candidate for franchisees is facing - many candidates who try and fail to obtain financing just go away and give up. Over the years, there have been witnessed more franchises being awarded a loan needed if the franchisor actually gets involved in the process. Not only do franchisors provide a sound and verified business plan, but some actually go with the candidate to visit the lender. Nobody knows how to present the opportunity better than the franchisor. This has worked for several franchisors in the past, especially when financing gets tight these days.

\subsection{Organisational structure}

The flat hierarchy structure of the creative team also contributes to a thriving work environment and culture. Employees' and franchisees' contributions to the design, the voice, and the style of the franchise brand are usually motivating for themselves and enriching for the whole brand and company. Franchisor has to create such a social structure and working environment that will make the work and the product interesting and exciting not only for the customer but also for the employee and franchisee.

\section{Conclusion}

This paper has presented results of empirical quantitative research and exploratory interviews where creativity was studied in franchising systems. Results of the research have shown that the perception of creativity allowed in franchise business models differs between franchisors and franchisees, and generally it has shown that franchisors do assess the level of creativity allowed as higher than as it is seen by franchisees.

There was a hypotheses testing conducted, using chi-square test. The hypothesis stating that perception of freedom of creativity given in the franchise systems is identical. This hypothesis was not rejected in two out of ten areas studied. Therefore it was further studied, mainly though descriptive analysis and comparison of data, counts and distribution patterns, how does the perception and levels of creativity in the franchises systems differ when evaluated and perceived form the viewpoint of the franchisors and franchisees.

Based on the research results it has been concluded in this paper that creativity is enhanced and can be found only in selected and limited areas and samples of franchising systems, whereas some areas are far from allowing creativity. Creative industries as a sample representative sector with a high level of creativity influencing the business success are not very often seen run as franchise system. Results from empirical research provide significant implications for discussions around creativity in franchising business model strategies. Implications for creativity presence in franchising business models are discussed for various areas in the franchising business model such as global branding, marketing and advertising, human resources, finance and accounting, administration etc. The conclusion is that from its essence the business model of franchising networks does not really enhance creativity as it is opposed to unified concepts in entrepreneurship, however it is also found that creativity and innovation should be facilitated by franchisors and franchisees to be able to flexibly respond to changing customers needs and requirement with new and innovative products or services offered.

The need of creativity and innovation enhancement in business for the purpose of its long-term success and deliver of products or services that would continuously manage to 
satisfy the needs and requirements of their customers is looked for in franchising systems as well. However franchise business operations are from its essence governed by various rules and brand unified policies and guidelines, to maintain the concept of unified brand and entrepreneurship concepts the same globally. Further the research and study has focused on finding examples and areas, where it is possible to enhance and regulate creative thinking of franchisees in the direction that would be benefiting for the system and not harming the concept, business model and unified look. The major finding is that the area of human resources management allows the highest level of creativity as perceived by both franchisors and franchisees and motivating employees is one of the two most important things a franchisee must do to see the impact of creativity bringing innovative, novel products or services that would be meaningful to all stakeholders franchisees, employees and customers. As franchising should be about long-term sustainability it has to attract motivated entrepreneurs and support their motivation in running their business, showing financial results and maintaining continuous development of relationship with their customers through offering new products. Relationship with employees assuring long-term sustainability should be enhanced by inspiring and motivating environment that motivates them to creativity benefiting the whole system. Respondents of exploratory interviews offered first ideas and it was found out that there exist several franchise systems that strongly support creative ideas sharing. Creativity in international franchising network should manage to tell the story of the franchise itself in each and every little detail and to articulate the brand on a global and international level. Thus it should not be regarded as danger for franchise system and its policies and rules. There are now several directions where further research can go to bring new findings of specific areas and field where creativity can be enhanced for further development of franchise systems and operations.

\section{References}

Amabile, T. M., R. Conti, H. Coon, J. Lazenby, \& M. Herron (1996). Assessing the Work Environment for Creativity. Academy of Management Journal 39,5: 1154-1184.

Amabile, T. M. (1983a). The Social Psychology of Creativity. New York: Springer-Verlag.

Amabile, T. M. (1983b). The Social Psychology of Creativity. New York: Springer-Verlag.

Andrews, J. \& Smith, D. C.(1996).In Search of Marketing Imagination: Factors Affecting the Creativity of Marketing Programs for Mature Products. Journal of Marketing Research, 33, 174-187.

Hallman, R.J. (1970). Toward a Hindu Theory of Creativity. Educational Theory, 20 (4), 368-376.

Hofstede, (1990). Cultures and organisations: Software of the mind. New York: McGraw Hill.

Howkins, J. (2001a). The Creative economy: How People Make Money From Ideas. London: Penguin books.

Howkins, J. (2001b). The Creative economy: How People Make Money From Ideas. London: Penguin books.

Hughes, A. O. \& Drew, J.S. (1984). A state creative? Papers in the Social Science, 4, 1-15.

Im, S., \& Workman, J. P. (2004). Market Orientation, Creativity, and New Product performances in High-Technology Firms. Journal of Marketing, 04, 114-137.

Jacobs, J. F. \& Pierce, M. L. (1966). Bilingualism and Creativity. Journal of Elementary English, v. 43, p. 499-503. 
Lakoff, G. \& Johnson, M. (1980). Metaphors We Live By. Chicago, IL, University of Chicago Press.

Landry, C., \& Bianchini, F. (1995). The Creative City. London: Demos.

Ricciardelli, L. A. (1992). Bilingual and cognitive development in relation to threshold theory. Journal of psycholinguistic research, v. 21, n. 4, 301-306.

Sethi, R., Smith, D.C. \& Park, C. W. (2001). Cross-Functional Product Development Teams, Creativity, and the Innovativeness of New Consumer Products. Journal of Marketing Research, 18, 73-85.

Simonton, D. K. (2008). Bilingualism and creativity: An introduction to bilingualism: principles and processes. In J. Altariba \& R. R. Heredia (Eds.) An introduction to Billingualism: Principles and processes (pp. 147-166). Mahwah, NJ. Erlbaum.

Sternberg, R. J. \& Kaufman, S. B. (2011). The Cambridge Handbook of Intelligence (Eds.). New York, NY: Cambridge University Press.

Sternberg, R. J. (1999a). The Handbook of Creativity. Cambridge University Press.

Sternberg, R. J. (1999b). The Handbook of Creativity. Cambridge University Press.

Sternberg, R. J., \& Lubart, T. I. (1999). The concept of creativity: Prospects and paradigms. In R. J. Sternberg (Ed.), Handbook of creativity (pp. 3-15). New York: Cambridge University Press.

Whorf, B. L. (1956). Language, Thought, and Reality: Selected Writings. Cambridge: Technology Press of Massachusetts Institute of Technology

Ing. Vendula Machackova, MSc.,

Technical University Liberec, Faculty of Economy, tel: 00420608247 257, e-mail: vendula.machackova@pearshealthcyber.com 